\title{
Conceptual Design and Numerical Simulations of Hypersonic Waverider Vehicle
}

\author{
D. Y. Cao*, J. B. Zhang, C. H. Lee
}

School of Aeronautic Science and Technology, Beijing University of Aeronautics and Astronautics Beijing 100083, China

Email: CaoDy@ase.buaa.edu.cn

\begin{abstract}
A modularized airframe/propulsion integrated model is established by oblique shock wave theory, engineering method and method of characteristics(MOC). Based on this method, a new design methodology for hypersonic waverider vehicle which integrated scramjets with waverider airframe derived from cone-wedge flow field is presented. Integrated aero-propulsion performance of the waverider vehicle under on-design and off-design conditions is predicted using Euler equations discretized by Harten-Yee non-MUSCL TVD scheme and the combustor flow field is approximated by a quasi-1D cycle analysis, skin friction of vehicle is calculated by reference temperature method.

According to the numerical simulations it shows that the hypersonic waverider vehicle designed in this paper not only has a multi-level pre-compression fore-body which can reduce inlet design difficulties and provide uniform air flow for scramjet but also has the whole waverider airframe which can provide high lift-to-drag ratio. Therefore the integrated design methodology developed in this paper can be used in designing the elementary configuration for practical air-breathing hypersonic vehicles.
\end{abstract}

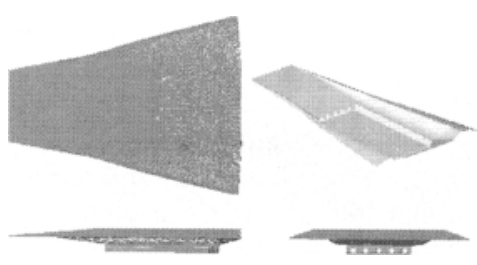

Figure: Configuration of primary hypersonic waverider vehicle

\section{REFERENCES}

1. Zhao GL, Hu L, Wen J, et al. An Overview of The Reseach on Waveriders and Waverider-Derived Hypersonic Vehicles. Advances in Mechanics, 2003; 33: 357-374

2. O'Neill M K, Lewis M J. Design tradeoffs on scramjet engine integrated hypersonic waverider vehicle. Journal of Aircraft, 1993; 30:943-952

3. Zheng B, Lee C-H. The effects of limiters on high resolution computations of hypersonic flows over bodies with complex shapes. Comm Nonlin Sci Numer Simul, 1998, 3: 82-87 